\title{
Normal Streamflows and Water Levels Continue: Summary of Hydrologic Conditions in Georgia, 2014
}

The U.S. Geological Survey (USGS) South Atlantic Water Science Center (SAWSC) Georgia office, in cooperation with local, State, and other Federal agencies, maintains a long-term hydrologic monitoring network of more than 350 real-time, continuous-record, streamflow-gaging stations (streamgages). The network includes 14 real-time lakelevel monitoring stations, 72 real-time surface-water-quality monitors, and several water-quality sampling programs. Additionally, the SAWSC Georgia office operates more than 204 groundwater monitoring wells, 39 of which are real-time. The wide-ranging coverage of streamflow, reservoir, and groundwater monitoring sites allows for a comprehensive view of hydrologic conditions across the State. One of the many benefits this monitoring network provides is a spatially distributed overview of the hydrologic conditions of creeks, rivers, reservoirs, and aquifers in Georgia.

Streamflow and groundwater data are verified throughout the year by USGS hydrographers and made available to water-resource managers, recreationists, and
Federal, State, and local agencies. Hydrologic conditions are determined by comparing the statistical analyses of data collected during the current water year ${ }^{1}$ (WY) to historical data. Changing hydrologic conditions underscore the need for accurate, timely data to allow informed decisions about the management and conservation of Georgia's water resources for agricultural, recreational, ecological, and watersupply needs and in protecting life and property.

\section{Water Resources Internet Tools}

Historically, hydrologic data collected by the USGS were compiled in annual data reports, but this method of publication was discontinued. Current and historical data are available through the National Water Information System Web interface, or NWISWeb, at http://waterdata.usgs.gov/nwis (U.S. Geological Survey, 2014a).

The USGS has several online waterresource tools designed to provide users with current streamflow and groundwater data, flood inundation maps, stream statistics, and
Quarterly Hydrologic Conditions in Georgia for 2014 WY, Based on Drainage Basin Runoff
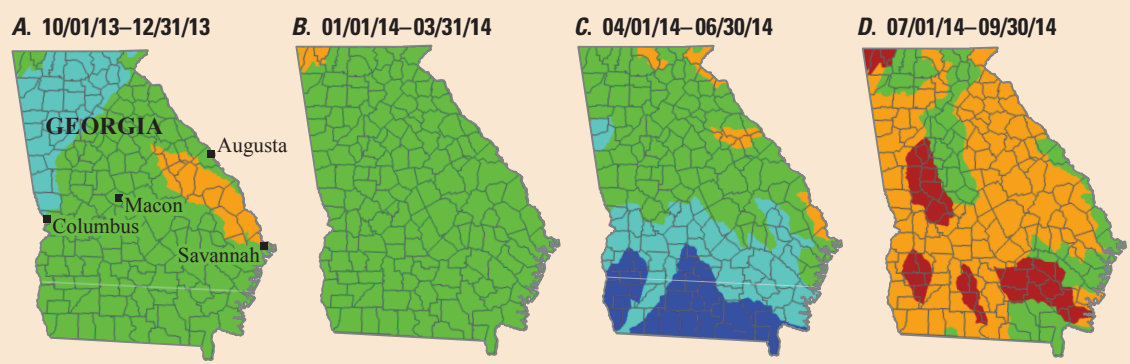

These maps represent hydrologic conditions during the 2014 WY compared with available historical data. The observed runoff-flow per unit area-is a good indicator of precipitation and streamflow conditions for a given basin (Langbein and Iseri, 1960). Runoff is calculated for each basin and presented uniformly over the entire basin area. Only streamflow stations with complete daily-flow datasets for the 2014 WY were used (U.S. Geological Survey, 2014c).

The average annual precipitation for Georgia ranges from 45 to 75 inches of rain. In the 2014 WY, the majority of the State received between 40 and 70 inches of rainfall (National Oceanic and Atmospheric Administration, 2014). For the first quarter of the 2014 WY (October-December 2013, map A), the majority of the State observed "normal" (25-75 percentile class) to "above normal" (76-90 percentile class) runoff conditions. During the second quarter of the 2014 WY (January-March 2014, map B), the runoff conditions were almost entirely "normal" (25-75 percentile class). During the third quarter of the 2014 WY (April-June 2014, map C), runoff conditions in the south were "much above normal" (>90 percentile class). During the fourth quarter (July-September 2014, map D), the State received 2-4 inches less than normal precipitation at the majority of National Weather Service monitoring locations (Dunkley, 2015). The cities of Macon and Columbus, Georgia, experienced the 2nd and 6th driest months on record, respectively, in August; the majority of runoff conditions were "below normal" (10-24 percentile class) and "much below normal" (less than 10 percentile class). water-quality information (Shaffer, 2013). Two of these Internet tools are WaterNow and WaterAlert. WaterNow, available at http://water.usgs.gov/waternow/, allows users to request current data for a USGS site by text messaging or emailing using a mobile phone. WaterAlert, available at http://water.usgs.gov/ wateralert/, notifies a user by text message or email when a user-defined threshold is exceeded at a real-time USGS site. Beginning with water year 2006 and ending with water year 2013, annual water data reports are available to the entire Nation as individual electronic Site Data Sheets. Starting with the 2014 WY, NWISWeb provides an on-demand, print-ready Water-Year Summary as an annual water-data product (U.S. Geological Survey, 2014b). Each site is assigned a unique USGS station number, and information on station numbers, alongside numbers for wells and miscellaneous sites, can be found at http:/help.waterdata.usgs.gov/faq/sites/dostation-numbers-have-any-particular-meaning.

Selected USGS Water Resources Internet Tools USGS National Water Information System (NWIS)

http://waterdata.usgs.gov/nwis

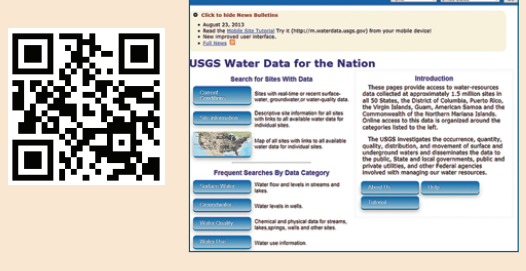

USGS WaterNow

http://water.usgs.gov/waternow/

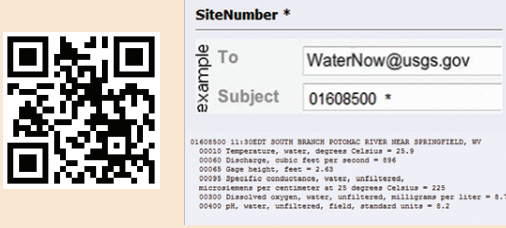

USGS WaterAlert

http://water.usgs.gov/wateralert/

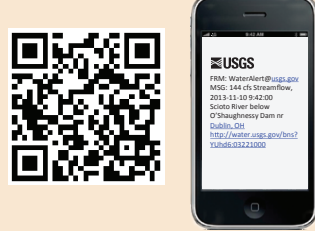
2013) 


\section{Chattooga River at Summerville, Ga. 02398000}

The Chattooga River flows from the northwestern corner Physiogranic Province, into Alsographic Province, into wabs Survey, 1975). For the majority of the 2014 WY 7 -day a orag streamflow conditions were "normal" to "much above normal." Daily discharge for most of the 2014 WY was in the "maximum" range. A new record-high daily discharge was observed on April 8.
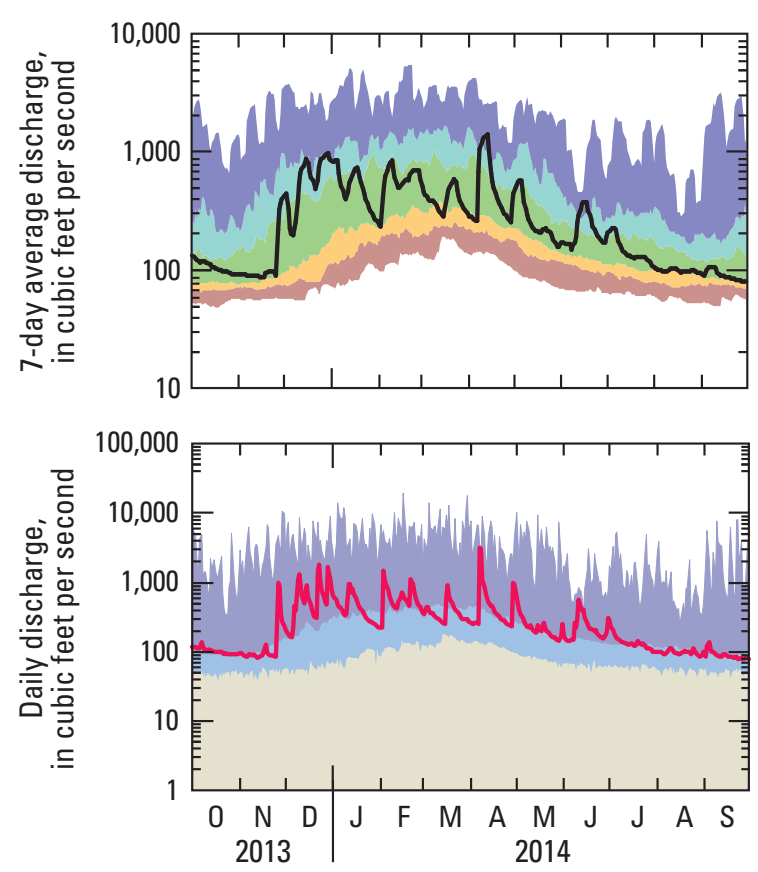

\section{Ocmulgee River at Macon, Ga. 02213000}

The $0 \mathrm{cmulgee} \mathrm{River} \mathrm{flows}$ out of Jackson Lake and joins Altamaha River in the Coastal Plain Physiogranhic Prosinal central Gorgia (US. Geove in Survey, 1975). In the 2014 WY the 7-day average discharges the 7-day average discharges were mostly "normal." Daily
discharge fluctuated between the "median" and "maximum" ranges of historical daily-mean flow, and record-high maximum daily-mean discharges were recorded during the month of December.

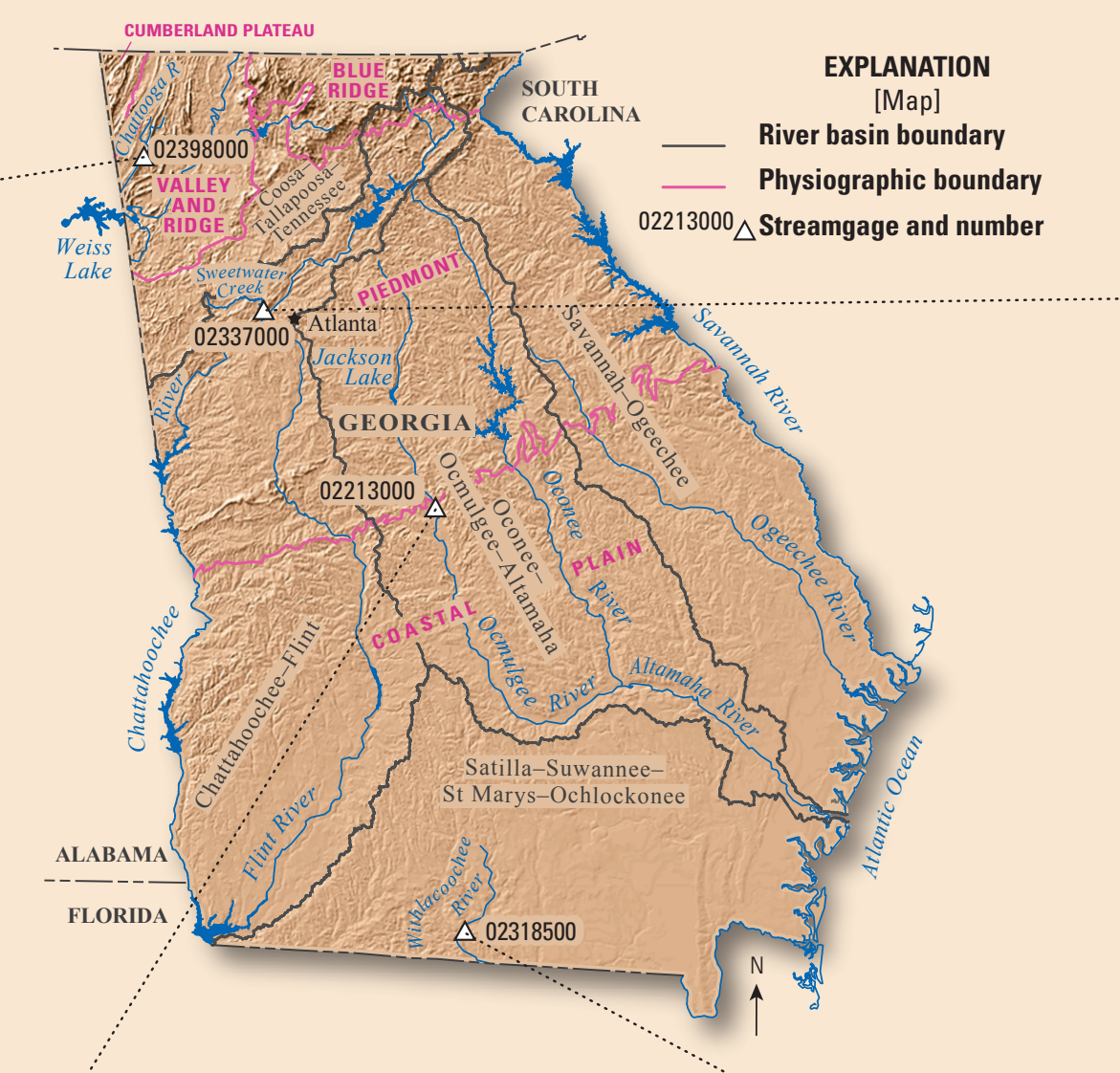

\section{EXPLANATION}

7-Day Average Discharge

Hydrographs show the 7-day average discharge for 2014 as compared to historical 7-day averages. Data are categorized in percentile ranges from "much above normal" (greater than the 90th percentile to "much below normal" (less than the 10th percentile) (U.S. Geological Survey, 2014c).

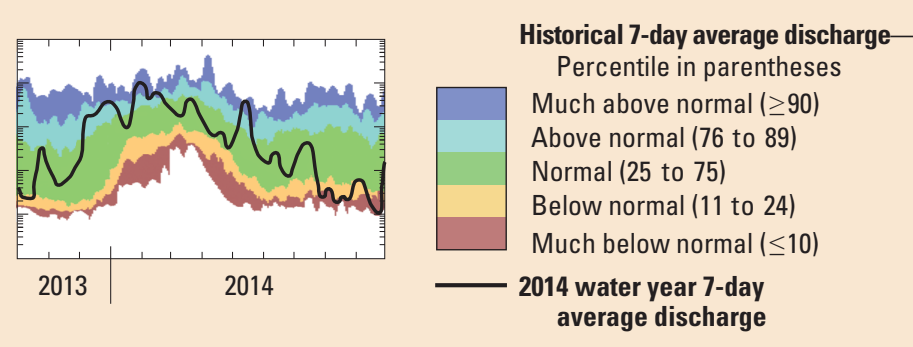

Daily Discharge

Hydrographs show 2014 daily-mean discharge, in cubic feet per second, as (ompare entre period

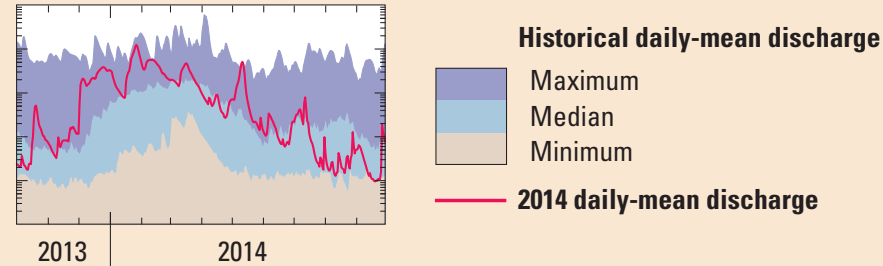

Sweetwater Creek near Austell, Ga. 02337000

Sweetwater Creek is a major Poochee River in the Piedmont Physiographic Province in central Georgia (U.S. Geological Surver, 1975). For the 2014 WY 7 -day average streamflow conditions were "normal" to "much above normal" with short periods of record in the "below normal" range. Daily discharge fluctuated between the "median" and "maximum" ranges of historical daily mean flow
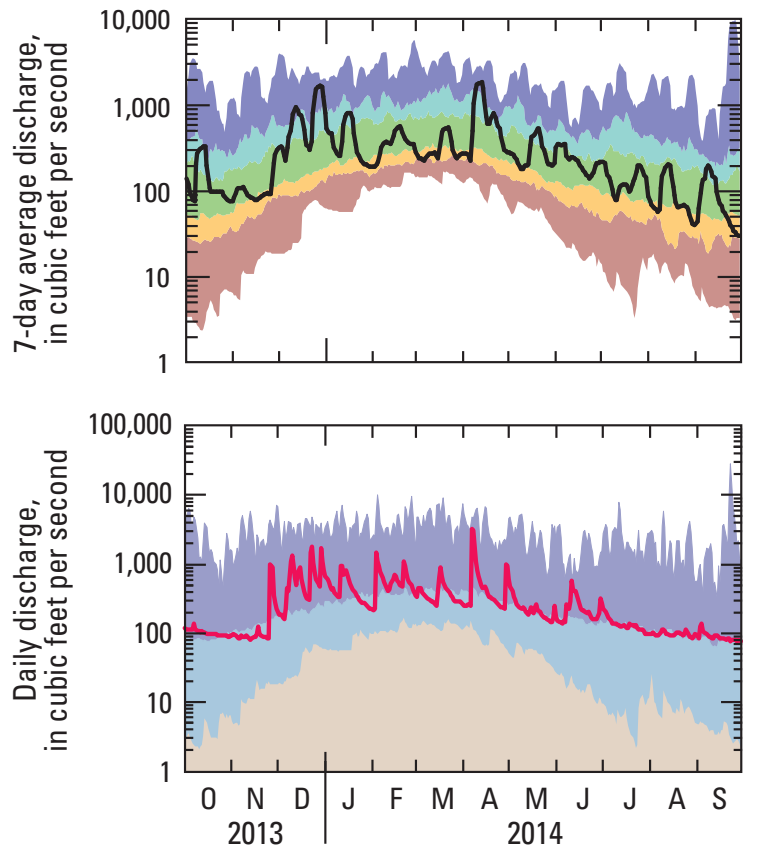

\section{Withlacoochee River at US 84 near Quitman, Ga. 02318500}

The Withlacoochee River flows into the Suwannee River Basin in the southern coastal plain of Georgia (U.S. Geological Sirvey, 7-day average streamflow 7-day average streammllow" to "much above normal," from October to May and record-high 7-day average streamflows were observed during April and MayDaily discharge was mostly in the "maximum" range from October to May, and record-high maximum daily-mean discharges were recorded during May
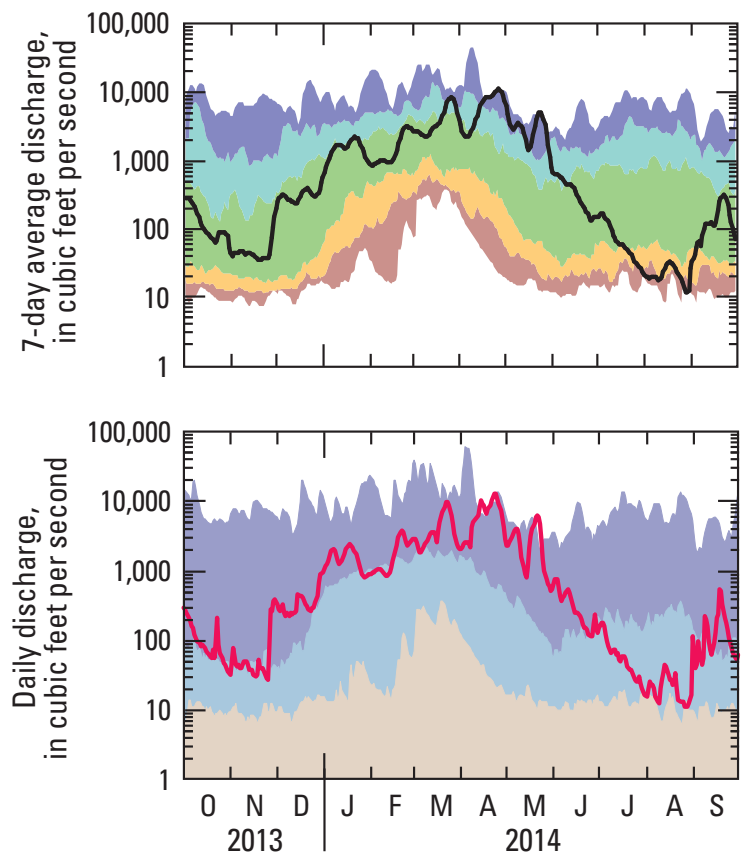


\section{Climate Response Network}

The USGS maintains a network of groundwater wells to monitor the effects of droughts and other climate variables on groundwater levels. These wells are part of the Climate Response Network, which measures the effects of climate on groundwater levels in unconfined aquifers or U.S. Geological Survey, 2014d). The nationg or other human influences on groundwater levels are minimal (Cunningham and others, 2007; part of the USGS Groundwater Resources and Cooperative Water Programs. The current conditions of groundwater wells in the Climate Respon Network can be accessed online at http://groundwaterwatch usgs gov/. The hydrographs presented in figure 4 are for select wells in Georia having at least 5 years of continuous data.

\section{OUSGS , Fin:}

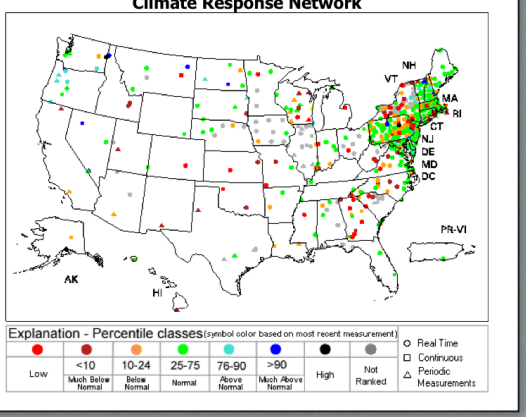

U.S. Climate Response Network can be accessed online at http://groundwaterwatch. usgs.gov/.

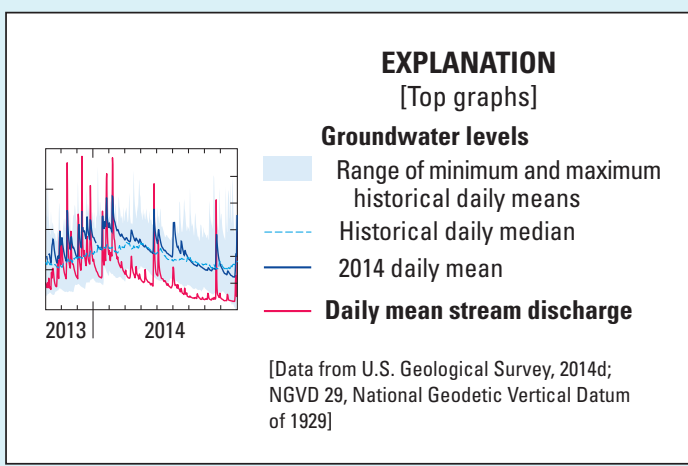

Well 07 H003 in Miller County in southwestern Georgia is completed in the surficial aquifer, which is an unconfined aquifer in this area (Peck and others, 2013). Water levels in this well usually rise rapidly during wet periods and decline

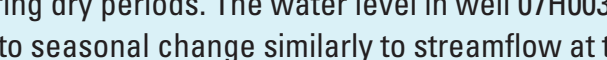
nearby streamgage on Ichawaynochaway Creek at Milford Georgia (station no. 02357000), which indicates atmospheric surface-water, and groundwater interactions. The water level in well $07 \mathrm{H} 003$ was above the historical daily median at the start of the $2014 \mathrm{WY}$. New maximum daily-mean water levels were recorded during the month of May after the area received more than 13 inches of rain in April. The water level slowly declined below the historical daily median from July through September

Well 03PP01, Walker County

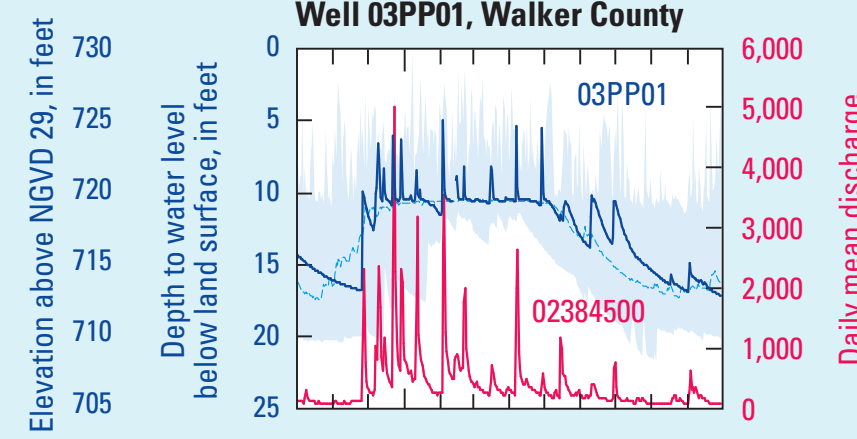

Well 03PP01 in Walker County in northwestern Georgia is Whe Palezoic-rock aquirer in the Chickamauga . and other 2013). Water levels are inflenced manly by precipitation and local pumping (Crester 1964) The war evelin well 03PP01 responds to season cha The similar to streamflow at the nearby streamgage on the Conasuga River near Eton, Georgia (station no. 02384500 ) which indicates tmosheric, surface-water, and groundwer interactions The water level in well 03PP01 was near the historical daily median throughout the 2014 WY and above the historical daily median from June through August. New maximum daily-mean water levels were observed in December 2013 and April 2014.

EXPLANATION

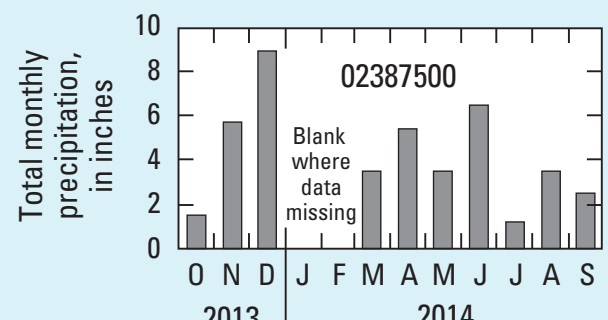

2014
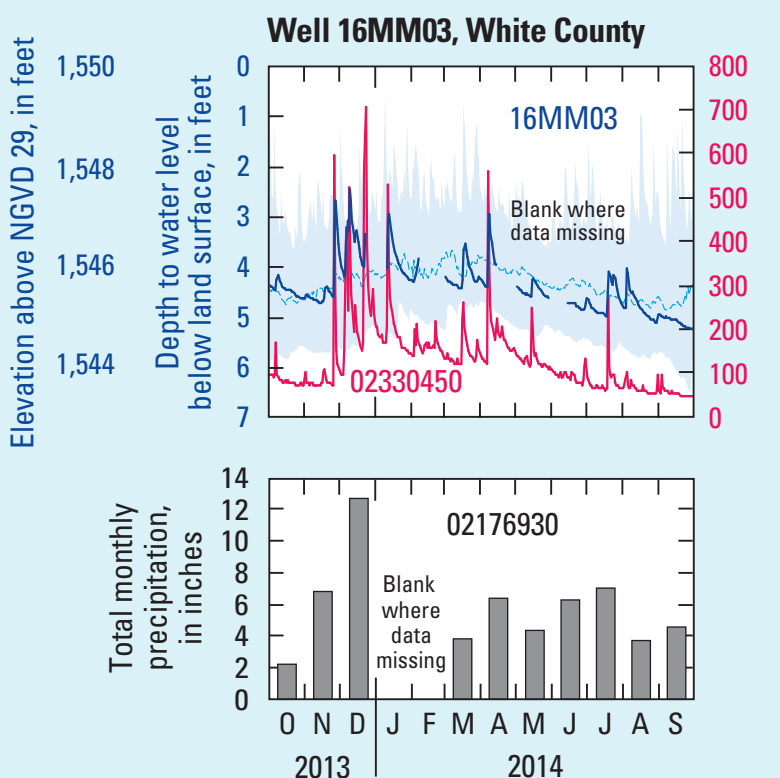

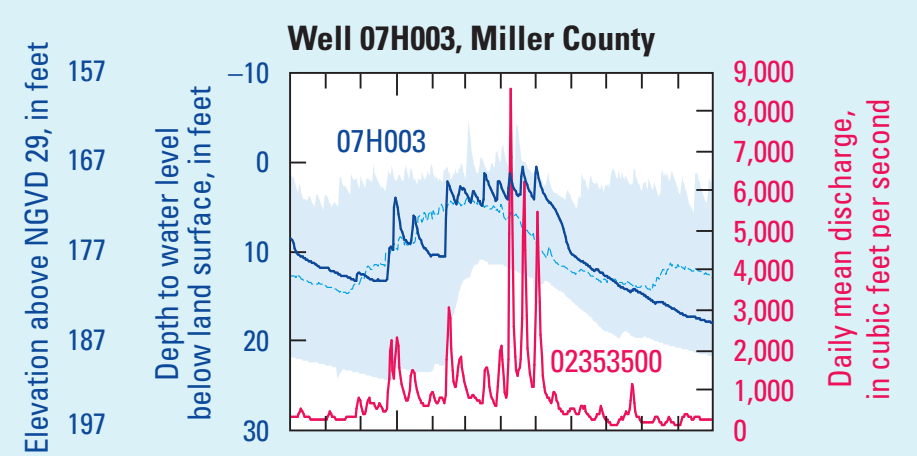

\section{and identifier}

Response Network number

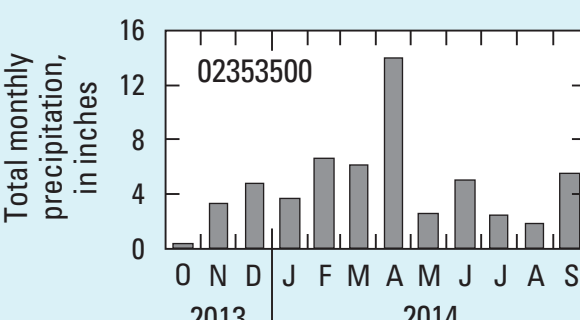

074003

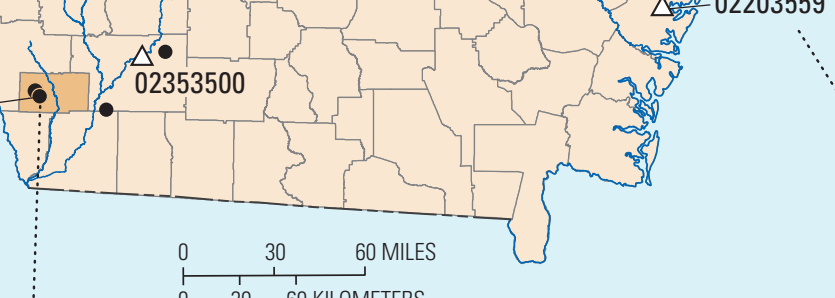

2013
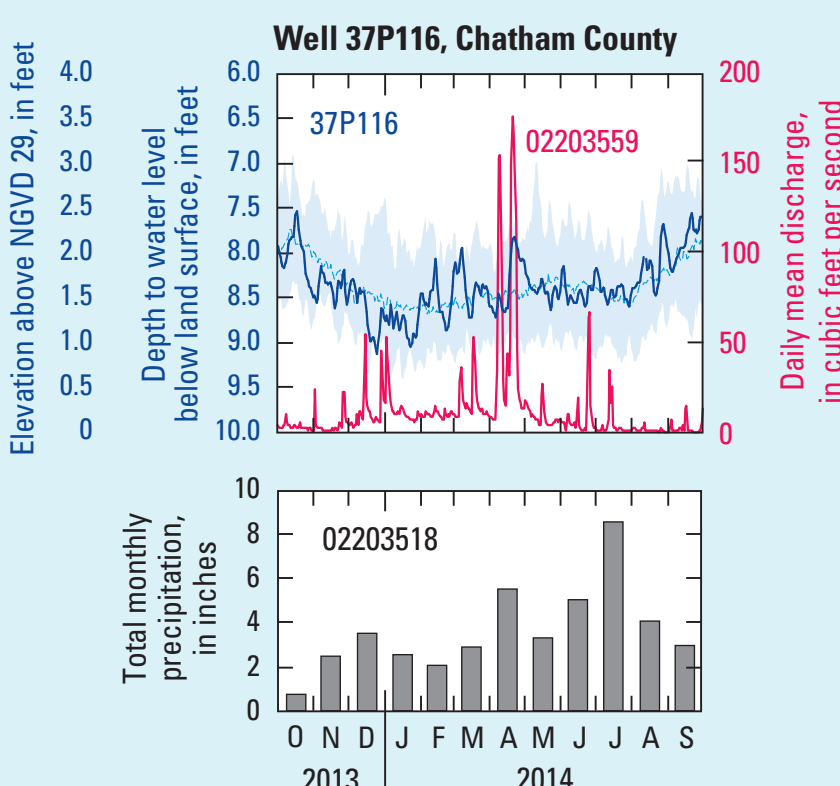

Well 16MM03 in White County in northeastern Georgia is completed in the crystalline-rock aquifer. Water is stored in the regolith and fractures, and the water level is affected by precipitation and evapotranspiration (Cressler and others, 1983). Precipitation can cause a rapid water-level rise in we tapping aquifers overlain by thin regolith (Peck and others,
2013). The water level in well $16 \mathrm{MM} 03$ responds to seasonal change similarly to streamflow at the nearby streamgage on the Chattahoochee River in Helen, Georgia (station no. 02330450), which indicates atmospheric, surface-water, and groundwater interactions. Normal condions conthued in the $2014 \mathrm{WY}$, and the daily-mean water levels fluctuated above and below the historical daily median throughout the water year. In December the area received more than 12 inches of precipitation and new maximum daily-mean water levels were observed on several days.

Well 37 P116 in Chatham County in southeastern Georgia is completed in the surficial aquifer. In most cases, water levels rise rapidly during wet periods and decline slowly during dry periods. The water level in well 37P116 responds to seasonal change similarly to streamflow at the nearby streamgage on Peacock Creek near McIntosh, Georgia (station no. 02203559), which indicates atmospheric, surface-water, and groundwater and blow he historic daily medion throughout the water new minimum daily-mean wat loug few days in Decomer 2013. new maximum daily-mean water levels were observed for a few days in April 2014. 


\section{Lakes and Reservoirs}

Major lakes and reservoirs throughout Georgia are managed primarily by the U.S. Army Corps of Engineers and Georgia Power Company in providing water for public and industrial use, flood protection, power generation, wildlife management, and recreation. To help manage lakes and reservoirs, tools such as computer models rely on real-time USGS streamflow data to predict changes in climatic conditions and water demands.

Lake Sidney Lanier on the Chattahoochee River is the primary drinking-water source for Metropolitan Atlanta. Lake Sidney Lanier is the farthest upstream reservoir in a series of reservoirs that include West Point Lake, Walter F. George Lake, and Lake Seminole. For the 2014 WY, total inflow was nearly equal to the total outflow and the water-level elevation remained near full pool. In August and September, the water-level was lowered as inflows declined, and the elevation was

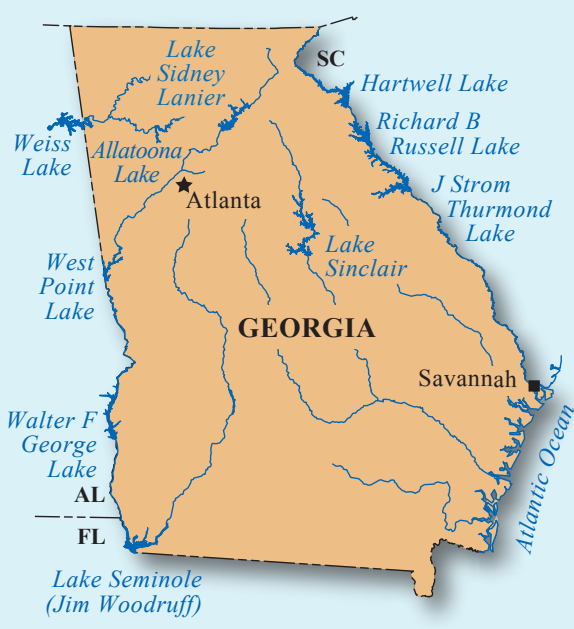

\section{References Cited}

Cressler, C.W., 1964, Geology and ground-water resources of Walker County, Georgia: Georgia Geologic Survey Information Circular no. 29; 15 p., accessed August 1, 2015, at https://epd.georgia.gov/sites/epd. georgia.gov/files/related_files/site_page/IC-29.pdf.

Cressler, C.W., Thurmond, C.J., and Hester, W.G., 1983, Groundwater in the greater Atlanta region, Georgia: Georgia Geological Survey Information Circular no. 63, 144 p. [Also available at http://ga.water.usgs.gov/ publications/ggs/ic-63/.]

Cunningham, W.L., Geiger, L.H., and Karavitis, G.A., 2007, U.S. Geological Survey ground-water Climate Response Network: U.S. Geological Survey Fact Sheet 2007-3003, 4 p., accessed July 1, 2015, at http://pubs.usgs.gov/fs/2007/3003/

Dunkley, N., 2015, 2014 Annual EPD Air Quality Report: Georgia Department of Natural Resources, Environmental Protection Division, accessed August 1, 2015 , at http://amp.georgiaair.org/annualreports.shtml.

Langbein, W.B., and Iseri, Kathleen T., 1960, General introduction and hydrologic definitions: U.S. Geological Survey Water-Supply Paper 1541-A, 29 p., accessed August 1, 2015, at https://pubs.er.usgs.gov/publication/ wsp1541A.

National Oceanic and Atmospheric Administration (NOAA), 2014, 2014 precipitation maps for GeorgiaYearly - Water Year-Advanced Hydrologic Prediction Service: National Weather Service Web page, accessed December 1, 2014, at http://water.weather.gov/precip.
1067.92 feet on September 24, the lowest recorded elevation for the water year. Full pool elevation in September is 1,071 feet.

West Point Dam provides flood protection and hydroelectric power to Troup County, Georgia, and the dam's construction was authorized by the Flood Control Act of 1962 (U.S. Army Corps of Engineers, 2014c). During the 2014 WY, the water level of West Point Dam remained either above or just below the top of conservation pool.

Allatoona Lake, on the Etowah River, is managed by the U.S. Army Corps of Engineers Mobile District as a primary drinking-water source for surrounding counties, as a flood control mechanism, and for hydropower generation. During the 2014 WY, total inflow was nearly equal to total outflow, and the water level of Allatoona Lake remained either above or just below the top of conservation pool.

Hartwell Lake is on the border between Georgia and South Carolina on the Savannah and Tugaloo Rivers, and it is the most upstream major reservoir on the Savannah River. Water is released to two downstream reservoirs: the Richard B. Russell and J. Strom Thurmond Lakes. These three lakes on the Savannah River are managed by the U.S. Army Corps of Engineers Savannah District for water supply, power generation, and the water-quality needs of the Savannah River from below Thurmond Dam to Savannah, Georgia, and the Atlantic Ocean (U.S. Army Corps of Engineers, 2014a). For the 2014 WY, total inflow was nearly equal to total outflow, and the water-level elevation remained near full pool. In August and September, the water level in Hartwell Lake lowered as inflows declined. The elevation declined to 656.35 feet on September 24 (3.65 feet below full pool) making it the lowest recorded elevation for the water year.

Peck, M.F., Gordon, D.W., and Painter, J.A., 2013, Groundwater conditions in Georgia, 2010-2011: U.S. Geological Survey Scientific Investigations Report 2013-5084, 63 p. [Also available at http://pubs.usgs.gov/sir/2013/5084/.]

Shaffer, K.H., 2013, U.S. Geological Survey water resources Internet tools: U.S. Geological Survey Fact Sheet 2013-3072, 2 p., accessed July 1, 2014, at http://pubs.usgs.gov/fs/2013/3072/.

U.S. Army Corps of Engineers, 2014a, Hartwell Dam and Lake: U.S. Army Corps of Engineers, Savannah District Web page, accessed December 1, 2014, at http://www.sas.usace.army.mil/About/Divisionsand Offices/OperationsDivision/HartwellDamandLake.aspx.

U.S. Army Corps of Engineers, 2014b, Lake elevations, inflows and outflows, accessed December 1, 2014, at http://water.sas.usace.army.mil/cf/DataQuery/ DataQuery.cfm.

U.S. Army Corps of Engineers, 2014c, West Point Lake: U.S. Army Corps of Engineers, Mobile District, accessed December 1, 2014, at http://www.sam. usace.army.mil/Missions/CivilWorks/Recreation/ WestPointLake.aspx.

U.S. Geological Survey, 1975, Hydrologic unit map —1974, State of Georgia: U.S. Geological Survey Numbered Series 10, scale 1:500,000, 1 plate.

U.S. Geological Survey, 2014a, National Water Information System-Web Interface: U.S. Geological Survey, Water Resources Web page, accessed December 1, 2014, at http://waterdata.usgs.gov/nwis.

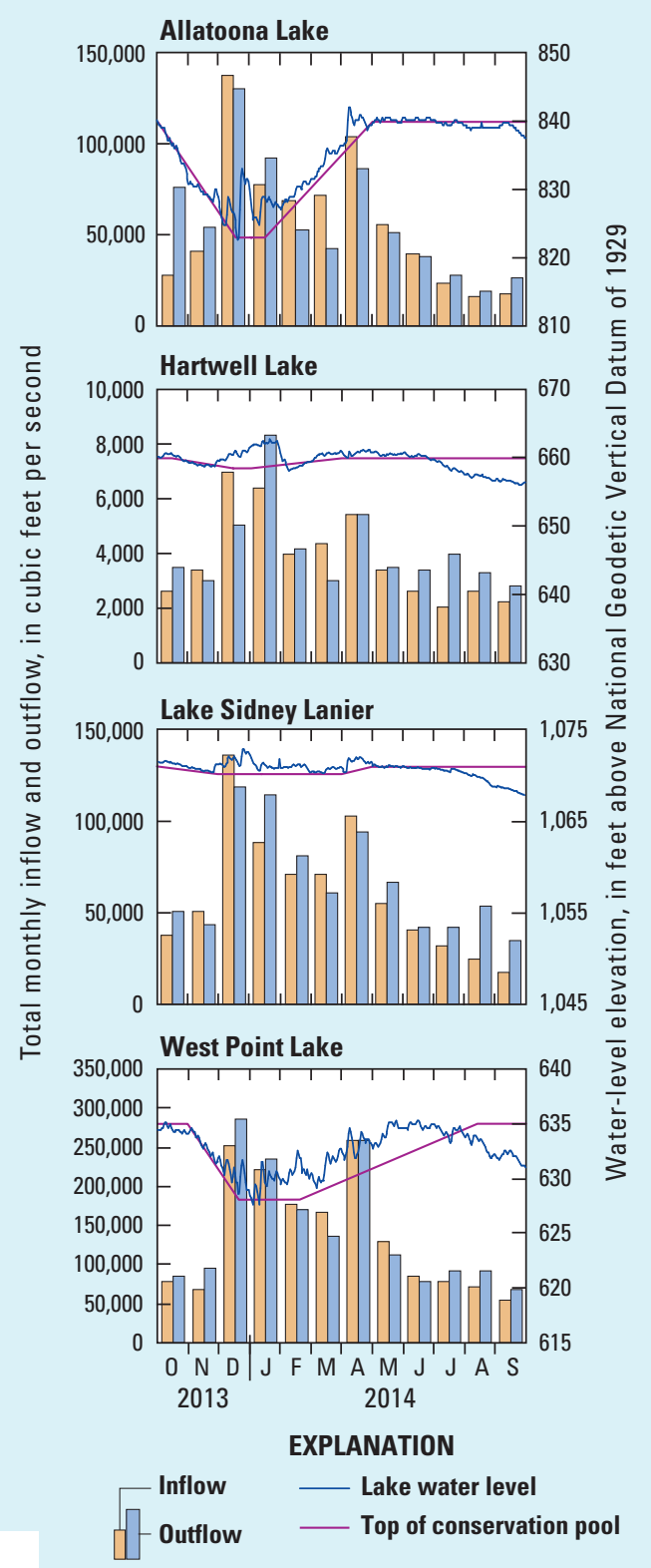

Inflow and outflow data from U.S. Army Corps of Engineers (2014b)

U.S. Geological Survey, 2014b, Annual Water Data Report: U.S. Geological Survey Web page, accessed February 17, 2016, at http://waterdata.usgs.gov/ga/nwis/.

U.S. Geological Survey, 2014c, WaterWatch - Current water resources in Georgia: U.S. Geological Survey Web page, accessed December 1, 2014, at http://waterwatch.usgs.gov/index.php?r=ga\&id=pa07d.

U.S. Geological Survey, 2014d, USGS groundwater watch: Office of Groundwater, U.S. Geological Survey Web page, accessed December 1, 2014, at http://groundwaterwatch.usgs.gov/.

By Andrew E. Knaak, Paul D. Ankcorn, and Michael F. Peck

For more information contact:

Director, South Atlantic Water Science Center U.S. Geological Survey

720 Gracern Road

Columbia, SC 29210

http://www.usgs.gov/water/southatlantic/

Water year is the period October 1 through September 30 and is designated by the year in which it ends. For example, the 2014 water year began on October 1, 2013, and ended on September 30, 2014. 